15) Joffe, J. \& D. Zudkevitsh: Chem. Eng. Progr. Symp. Ser., 63 (81), 43 (1967)

16) Kaminishi, G., Y. Arai, S. Saito \& S. Maeda: J. Chem. Eng. Japan, 1, 109 (1968)

17) Kang, T. L. \& J. J. McKetta: J. Chem. Eng. Data, 6, 227 (1961)

18) Kay, W. B. : Ind. Eng. Chem., 30, 459 (1938)

19) Kay, W.B.: ibid., 32, 353 (1940)

20) Kay, W. B. : ibid., 33, 590 (1941)

21) Kay, W. B. : ibid., 40, 1459 (1948)

22) Kay, W. B. \& T. D. Nevens: Chem. Eng. Progr. Symp. Ser., 48 (3), 108 (1952)

23) Kay, W. B. \& G. M. Rambosek: Ind. Eng. Chem., 45, 221 (1953)

24) Kay, W. B. \& D. B. Brice: ibid., 45, 615 (1953)

25) Kunen, J.P.: Z. Phisik. Chem., 24, 667 (1897)

26) Masuda, H. \& M. Yorizane: Kagaku Kōgaku, 32, 820 (1958)

27) Matschke, E. \& G. Thodos: J. Chem. Eng. Data, 7, 232 (1962)

28) McKay, R. A., H. H. Reamer, B. H. Sage \& W. N. Lacey : Ind. Eng. Chem., 43, 2112 (1951)

29) Nysewander, C. N., B. H. Sage \& W. N. Lacey: ibid., 32, 118 (1940)

30) Olds, R. H., B. H. Sage \& W. N. Lacey: ibid., 34, 1008 (1942)

31) Olds, R. H., H.H. Reamer, B.H. Sage \& W. N. Lacey: ibid., 41, 475 (1949)

32) Opfell, J. B., B. H. Sage \& R. S. Pitzer: ibid., 48, 2059 (1956)

33) Organick, E. I. \& W. R. Studhalter: Chem. Eng. Progr., 44, 847 (1948)

34) Poettman, F. H. \& D. L. Katz: Ind. Eng. Chem., 37, 847 (1945)

35) Price, A. R. \& R. Kobayashi: J. Chem. Eng. Data, 4, 40
(1959)

36) Reamer, H. H., R. H. Olds, B.H. Sage \& W. N. Lacey : Ind. Eng. Chem., 34, 1526 (1942)

37) Reamer, H. H., B. H. Sage \& W. N. Lacey: ibid., 43, 976 (1951)

38) Reamer, H. H., B. H. Sage \& W. N. Lacey : ibid., 45, 1805 (1953)

39) Reamer, H. H., B. H. Sage \& W. N. Lacey : J. Chem. Eng. Data, 1 (1), 29 (1956)

40) Reamer, H. H., B. H. Sage \& W. N. Lacey : ibid., 5, 44 (1960)

41) Reamer, H. H. \& B. H. Sage: ibid., 7, 161 (1962)

42) Reamer, H. H. \& B. H. Sage: ibid., 9, 24 (1964)

43) Reamer, H. H. \& B. H. Sage: ibid., 11, 17 (1966)

44) Redlich, O. \& A. T. Kister: J. Chem. Phys., 36, 2002 (1962)

45) Roberts, L. R. \& J. J. McKetta: A. I. Ch. E. Journal, 7, 173 (1961)

46) Sage, B. H., W. N. Lacey \& J. G. Schaafsma: Ind. Eng. Chem., 26, 214 (1934)

47) Sage, B. H. \& W. N. Lacey: ibid., 32, 992 (1940)

48) Sage, B. H., B. L. Hicks \& W. N. Lacey: ibid., 32, 1085 (1940)

49) Sage, B. H., H. H. Reamer, R. H. Olds \& W. N. Lacey: ibid., 34, 1108 (1942)

50) Schiller, F. C. \& L. N. Canjar: Chem. Eng. Progr. Symp. Ser., 49 (7), 67 (1953)

51) Spear, R. R., R. L. Robinson, Jr. \& K. C. Chao: I. \& EC Fundamentals, 8, 2 (1969)

52) Stotler, H. H. \& M. Benetict: Chem. Eng. Progr. Symp. Ser., $49(6), 25(1953)$

53) Vaughan, W.E. \& F. C. Collins: Ind. Eng. Chem., 34, 885 (1942)

54) Widdoes, L. C. \& D. L. Katz: ibid., 40, 1742 (1948)

\title{
LIQUID FILM COEFFICIENT OF MASS TRANSFER ON FREE LIQUID SURFACE*
}

\author{
TERUKATSU MIYAUCHI AND HIROSHI KATAOKA \\ Department of Chemical Engineering, University \\ of Tokyo, Tokyo
}

\begin{abstract}
The rate of surface renewal, defined by the ratio $v_{\lambda} / \lambda$, at the clean surface of isotropic turbulent liquid flow is highest for the smallest eddies with size $\lambda_{0}$ in the inertial subrange, where $\lambda$ is the size of eddies and $v_{\lambda}$ the fluctuating velocity. The eddies smaller than $\lambda_{0}$ are also shown to have a renewal rate the same as $\lambda_{0}$, thus indicating that the maximum possible liquid film coefficient of mass transfer is given by the equation reported previously for $\lambda_{0}$. New form of surface age distribution function at the clean surface of isotropic turbulent liquid is presented.
\end{abstract}

The surface renewal theory ${ }^{2)}$ for liquid film coefficient has been tested by various investigators. The rate of surface renewal has also been related to the nature of turbulent flow field. Among them, O'Connor et al. ${ }^{7}$ related the rate with the ratio of fluctuation velocity to mixing length, as follows, and applied it to correlate the data on the rate of oxygen absorption by rivers.

$$
s=v / l
$$

Another approach by Dobbins ${ }^{32}$ takes into consideration

* Received on June 7, 1969 the influence of surface tension, arriving at the expression that

$$
s=c_{1} \rho(\varepsilon \nu)^{3 / 4} / \sigma
$$

Fortesque et al. ${ }^{4)}$ presented Eq. (3) with the concept that the renewal is mainly governed by larger eddies:

$$
k_{L}=1.45\left(D_{L} u / A\right)^{1 / 2}
$$

Miyauchi et al. ${ }^{6)}$ took the somewhat different consideration that the rate of renewal is governed mainly by the eddies of smallest size, $\lambda_{0}$ which have the shortest time scale of fluctuation, and arrived at the expression that 


$$
\begin{aligned}
& s=c_{2}(\varepsilon / \nu)^{1 / 2} \\
& k_{L}=c_{3}(\varepsilon / \nu)^{1 / 4} D_{L}^{1 / 2}
\end{aligned}
$$

In this treatment the contribution of eddies smaller than $\lambda_{0}$ is not mentioned particularly. This point has been discussed as follows:

\section{Contribution of Eddies Smaller than $\lambda_{0}$}

The spectrum of turbulent eddy components is continuous even in the viscous subrange, although the eddies in this range decay rapidly with decreasing size, due to viscous dissipation. Also, fluctuating velocity and eddy size are governed by mechanisms different from those in the inertial subrange. So it is probable that the renewal rate of eddies in the viscous subrange is different from that in the inertial subrange.

The fluctuating velocity $v_{\lambda}$ of eddies with the size $\lambda$ in the former subrange, under the premise of local isotropy, is

$$
v_{\lambda}=c_{4}\left(\varepsilon \lambda^{2} / \nu\right)^{1 / 2}
$$

The rate of renewal $s$ is thus given by

$$
s \div v_{\lambda} / \lambda=c_{4}(\varepsilon / \nu)^{1 / 2}
$$

which is essentially the same as Eq. (4) except for the constant terms. These terms are considered about the same.

Thus Eq. (5) for the smallest eddies with $\lambda_{0}$ is seen still good even in this subrange, and gives the possible highest rate coefficient of mass-transfer. Due to this, Eq. (5) is adopted as the highest liquid film coefficient for clean liquid surface under turbulent condition.

Eq. (5) has also been given by Ruckenstein ${ }^{82}$ from dimensional consideration, and by Banerjee et al. ${ }^{1)}$ by utilizing the result of Lamont ${ }^{5)}$ on the basis that the shortest time scale for turbulent eddies is for the smallest ones. They, however, do not mention the roll of eddies smaller than the smallest one.

\section{Liquid Film Coefficient}

The above discussions show that a turbulent free liquid surface is composed of the superposition of eddies of various sizes. Of these the eddies of a size equal to or smaller than $\lambda_{0}$ are responsible for the possible highest liquid film coefficient. The characteristic age of these eddies $\tau_{m}$ is $\lambda / v_{\lambda}$, and this limits the maximum age for the eddies under steady renewal in the liquid surface. The characteristic frequencies of the renewal is also considered as $v_{\lambda} / \lambda$, since $v_{\lambda}$ is the characteristic mean fluctuating velocity. Thus

$$
s \approx v_{\lambda} / \lambda \approx 1 / \tau_{m} \approx(\varepsilon / \nu)^{1 / 2}
$$

The population balance on the age distribution of eddies in the liquid surface is

$$
d \phi(\tau) / d \tau=-s \phi(\tau)
$$

where $\phi(\tau)$ is the age distribution function. The bound- ary conditions for $\phi(\tau)$ are

$$
\begin{aligned}
& \tau>\tau_{m}: \phi(\tau)=0 \\
& \tau_{m}>\tau>0: \int_{0}^{\tau_{m}} \phi(\tau) d \tau=1
\end{aligned}
$$

Thus $\phi(\tau)$ is given as follows:

$$
\phi(\tau)=\frac{s \exp (-s \tau)}{1-\exp \left(-s \tau_{m}\right)}
$$

which gives the $\phi(\tau)$ by Danckwerts ${ }^{2)}$ when $\tau_{m} \rightarrow \infty$.

The mean liquid film coefficient $k_{L}$ is derived as follows:

$$
k_{L}=\frac{1}{\left(c^{*}-c_{0}\right)} \int_{0}^{\tau_{m}} \phi(\tau) \cdot\left(c^{*}-c_{0}\right) \sqrt{\frac{D_{L}}{\pi \tau}} d \tau
$$

or

$$
k_{L}=\frac{\operatorname{erf} \sqrt{s \tau_{m}}}{1-\exp \left(-s \tau_{m}\right)} \cdot \sqrt{\overline{D_{L} s}}
$$

where $s \tau_{m} \approx 1$, since $s \approx 1 / \tau_{m}$ by Eq. (8).

The coefficient of the term $\sqrt{D_{L} S}$ is on the order of one, ultimately giving an expression similar to the one reported previously ${ }^{6)}$.

\section{Nomenclature}

$c^{*} \quad=$ solubility of gas in liquid $\quad\left[\mathrm{mol} / \mathrm{cm}^{3}\right]$

$c_{0}=$ initial concentration of gas in bulk liquid $\left[\mathrm{mol} / \mathrm{cm}^{3}\right]$

$c_{1} \sim c_{5}=$ constant

$D_{L}=$ diffusion coefficient of gas in liqud $\left[\mathrm{cm}^{2} / \mathrm{sec}\right]$

$k_{L}=$ liquid-phase mass transfer coefficient $[\mathrm{cm} / \mathrm{sec}]$

$l=$ mixing length $[\mathrm{cm}]$

$s \quad=$ rate of surface renewal $[1 / \mathrm{sec}]$

$u=$ fluctuating velocity in $x$-direction parallel to surface

$[\mathrm{cm} / \mathrm{sec}]$

$v=$ fluctuating velocity in $y$-direction normal to $x$-direction

$[\mathrm{cm} / \mathrm{sec}]$

$A=$ integral length scale $\quad[\mathrm{cm}]$

$\lambda=$ scale of turbulence $\quad[\mathrm{cm}]$

$\lambda_{0}=$ scale of the smallest eddy $[\mathrm{cm}]$

$\sigma=$ surface tension of liquid $\quad[$ dyne $/ \mathrm{cm}]$

$y=$ kinematic viscosity of liquid $\quad\left[\mathrm{cm}^{2} / \mathrm{sec}\right]$

$\rho=$ liquid density $\quad\left[\mathrm{g} / \mathrm{cm}^{3}\right]$

$\varepsilon \quad=$ energy dissipation per unit mass $\quad\left[\mathrm{cm}^{2} / \mathrm{sec}^{3}\right]$

$\tau=$ time of exposure [sec]

$\tau_{m}=$ characteristic age or maximum age of eddies [sec]

$\dot{\phi}=$ age distribution function $\quad[1 / \mathrm{sec}]$

\section{Literature cited}

1) Banerjee, S., Scott, D. and Rhodes, E. : I. \& E. C. Fundamentals, 7, 22 (1968)

2) Danckwerts, P. V.: Ind. Eng. Chem., 43, 1460 (1951)

3) Dobbins, W. E. : J. San. Eng. Div., Proc. of ASCE, 90, No. SA 3, 53 (1964)

4) Fortesque, G. E. and Pearson, J. R. A. : Chem. Eng. Sci., 22, 1163 (1967)

5) Lamont, J. C. : Ph. D. thesis, British Columbia (1966)

6) Miyauchi, T. and Kataoka, H.: The Meeting of the Society of Chemical Engineers, Japan (July 1966, Osaka). Kataoka, H., and Miyauchi, T.: Kagaku Kōgaku, 33, 181 (1969)

7) O'Connor, D. J., and Dobbins, W. E. J. San. Eng. Div. of ASCE., 82, No.SA 6 (1956)

8) Ruckenstein, E.: Int. Chem. Engrs., 7, 490 (1967) 